\title{
Alijana Šantej \\ UNIVERZA ZA TRETJE ŽIVLJENJSKO OBDOBJE 30 LET POZNEJE
}

Društvo za izobraževanje za tretje življenjsko obdobje je nacionalna nevladna organizacija, v praksi poznana pod imenom Univerza za tretje življenjsko obdobje. S poimenovanjem te ustanove in določanjem njene jasne strukture smo imeli kar nekaj težav, tipičnih za organizacijo, ki hitro raste in se mora na svoji poti večkrat preoblikovati, če želi obstati. V 30 letih je bilo veliko pomembnih odločitev in vse so bile in so še nenehen vir učenja za vse, ki smo vpeti v razvoj področja in oblikovanje organizacije.

Financiranje, za katero so na začetku poskrbeli kar člani upravnega odbora ali je prihajalo zgolj iz enega vira, je danes zagotovljeno iz različnih virov, večinoma iz projektnih sredstev. Tudi dejavnost je bila sprva ena, to je izobraževanje starejših odraslih, danes je dejavnosti več: projektno delo na lokalni, nacionalni in mednarodni ravni, mreža slovenskih univerz za tretje življenjsko obdobje, izobraževanje mentorjev v izobraževanju starejših, svetovanje za dejavno staranje, medgeneracijski centri Znaš, nauči drugega, mednarodno sodelovanje in povezovanje, povezovanje starejših na področju izobraževanja in kulture ter predstavljanje njihov izsledkov v javnosti (npr. mednarodni festival znanja in kulture), publiciranje in založništvo, organizirano prostovoljno delo starejših v sodelovanju z javnimi ustanovami, javna kampanja, mentorstvo študentom, specialna knjižnica itd. Nekoč je bilo pomembno, da se dejavnost »postavi«, danes je bistvena kakovost njenega razvoja. Razvoj je bil sprva posvečen enemu ali dvema profiloma »uporabnikov«, danes obstaja razvojni načrt za več profilov »uporabnikov«.

\section{DELOVANIE V TREH SEKCIJAH}

Univerza za tretje življenjsko obdobje v Ljubljani je najpomembnejša sekcija društva, ki ima v letošnjem študijskem letu 3.400 študentov, vseh študentov v izobraževanju pa je več kot 4.600. Študenti se izobražujejo od dve do osem ur na teden vsaj osem mesecev v letu, mnogi tudi skozi vse leto. Razen tega se udeležujejo številnih drugih oblik izobraževanja, konferenc, posvetov, projektnih srečanj, seminarjev, izobraževalnih izletov, poletne univerze. Temeljna oblika in metoda dela sloni na načelih študijskega krožka. V študijskih skupinah univerze za tretje življenjsko obdobje so mentorji in študenti drug drugemu vir učenja, s svojimi izkušnjami, odkrivanjem in kulturo skupaj gradijo novo znanje zase in 
za skupnost. Študijske skupine vodita mentor in animator, ki si z drugimi člani delita odgovornost za vsebino in potek izobraževanja.

Druga sekcija je Slovenska univerza za tretje življenjsko obdobje, v kateri je združenih 46 univerz in več kot 20.000 študentov, skoraj 1000 mentorjev in domala 1000 prostovoljcev. Mreža pokriva Slovenijo skoraj brez sivih lis. Med pomembnejšimi projekti v zadnjem času so bili ustvarjanje mreže, ki povezuje nevladne organizacije na področju izobraževanja starejših in jih krepi, razvoj gibanja »Znaš, nauči drugega«, kjer gre za medsebojno računalniško opismenjevanje v dvojicah starejših, in projekt izobraževanje mentorjev specialistov za delo s starejšimi. To je bilo 80-urno usposabljanje 160 zdajšnjih ali prihodnjih mentorjev na slovenskih univerzah za tretje življenjsko obdobje in v drugih nevladnih organizacijah. Skozi načrtovanje in izvajanje usposabljanja mentorjev se je oblikoval program, ki je lahko zametek prihodnjega univerzitetnega študija za izobraževalce starejših. Če je univerzitetni študij potreben za izobraževalce otrok, študentov in odraslih, zakaj ne bi razvili tudi študijskega programa za izobraževalce starejših.

Slovenska univerza za tretje življenjsko obdobje ima tudi svoj Mednarodni festival znanja in kulture starejših. Festival je namenjen predstavitvi dosežkov študentov slovenskih univerz za tretje življenjsko obdobje v učenju in kulturi. Doslej so ga gostili v Škofji Loki in Novi Gorici.

Tretja sekcija društva je Inštitut za raziskovanje in razvoj izobraževanja. Sodelavci inštituta razvijajo nove programe, vodijo raziskave s področja socialne gerontologije in geragogike, povezujejo se z visokim šolstvom, skrbijo za stike z javnimi občili in ozaveščanje javnosti, vodijo domače in evropske projekte, sodelujejo z lokalno, nacionalno in evropsko ravnjo oblasti, sooblikujejo politiko do starosti in staranja in izobraževanja starejših. Inštitut je doslej izvedel 13 obsežnih evropskih projektov. Vsi so prinesli dobre rezultate in spodbudo za številne inovacije.

\section{RAZVOINA DEJAVNOST}

Društvo je leta 1995 v priročniku Prostovoljstvo starejših za starejše popisalo svoj prostovoljski razvoj in podalo ugotovitve za prenos znanja o prostovoljstvu. Zasnovalo je Mrežo prostovoljnih kulturnih mediatorjev $\mathrm{v}$ muzejih in bolnišnicah, program Umetnost prostovoljskega pripovedovanja in program Vrtni prostovoljci. Pri tem se povezuje z različnimi javnimi ustanovami, uvaja inovativno prakso, izobražuje starejše in osebje javnih ustanov, slednje za ustvarjanje novih, izvirnih prostovoljskih vlog za starejše. Za svoje delovanje so društvo in njegovi študenti prejeli številna občinska, državna, strokovna in stanovska priznanja, med njimi plaketo mesta Ljubljana, priznanje JAPTI za najboljšo družbeno inovacijo in državno nagrado na področju šolstva.

Društvo ima tudi specialno knjižnico, odprto za javnost. Vodi izobraževalno prakso za študente univerzitetnega študija in izdaja strokovno literaturo. Na temelju izkustva so razvili več področij (medgeneracijsko povezovanje, menedžment v socialnem delu) in na 
ravni univerzitetnega študija oblikovali program sociokulturne animacije in izobraževanja za lokalni razvoj, ki se izvaja na Oddelku za pedagogiko in andragogiko Filozofske fakultete v Ljubljani.

Univerza za tretje življenjsko obdobje se danes, 30 let po nastanku in 28 let po uradni ustanovitvi v okvirih Andragoškega društva Slovenije, posveča raziskovanju, razvoju, zagovorništvu in izobraževanju za osebnostno rast, boljšo zaposljivost, za plačano in prostovoljno delo starejših, izobraževanju za medgeneracijsko sodelovanje ter svetovanju za dejavno staranje. Poleg izobraževanja starejših je pomembna tudi kampanja za ozaveščanje javnosti, ki se tudi po 30 letih še kar ne ustavi. Vedno znova je treba premagovati stereotipe o starejših in utrjevati sodobno podobo tretjega življenjskega obdobja kot razvojno, ustvarjalno, svobodno in družbeno odgovorno obdobje. V družbi, ki se stalno spreminja, se moramo ne glede na starost vsi nenehno učiti, da bolje razumemo sebe in svet okrog nas, da smo samostojni in odgovorni, da ostanemo dejavni državljani tudi v poznejših letih in znamo prispevati v skupno dobro. Le tako imamo dovolj psihološke, ekonomske in politične moči, da lahko odločamo o sebi in skupnih rečeh.

Hvaležni smo živi verigi sodelavcev, prostovoljcev, somišljenikov, ki so v razvoj Univerze za tretje življenjsko obdobje vtkali svoja prizadevanja, razmišljanja, ideje, rešitve. Če jih na tem mestu ne omenjam, naš dolg do njih ni nič manjši. Oni vedo, da je njihovo delo prepleteno $\mathrm{z}$ našo zgodovino in našo sedanjostjo. Brez njih te univerze in njene osrednje vloge na področju izobraževanja starejših ter medgeneracijskega povezovanja ne bi bilo. 